\title{
COVID-19 and the Entertainment Industries in Nigeria
}

\author{
V.O Eze ${ }^{1}$, Uche Uwaezuoke Okonkwo², Cindy Anene Ezeugwu ${ }^{3}$ Chinyere \\ Christiana Ukwueze ${ }^{4}$ and Felicia O. Ezeugwu ${ }^{5}$ \\ ${ }^{1}$ Department of General Studies, University of Nigeria, Nsukka, virginia.eze@unn.edu.ng. \\ 2Department of History, University of Nigeria, Nsukka, ucheokonkwo20o7@yahoo.com \\ (Corresponding author) \\ ${ }^{3}$ Department of Theatre and Film Studies, University of Nigeria, Nsukka \\ cindyj246@gmail.com \\ ${ }^{4}$ Department of Music, University of Nigeria, Nsukka, chinyere.ukwueze@unn.edu.ng \\ 5Department of Music, University of Nigeria, Nsukka, felicia.ezeugwu@unn.edu.ng
}

\begin{abstract}
This paper examines not only on the socio-economic implication of the lockdown on practitioners in the entertainment industry namely the cinema halls, live performances, and the film industries among others, but also it explores the ways E-entertainment was being introduced especially in music and drama industry. With the lockdown orchestrated by the Covid-19 pandemic outbreak in Nigeria, show lovers were being entertained through E-concerts, drive in theatre performances, and television live shows like Owambe and Pepsi Dance Party that was being showed every weekend with the audience responding on face book, Instagram and WhatsApp platforms among others. The research method is qualitative and analytical. The study employed a survey method of data collection to gather relevant material from published and unpublished materials in hard and soft copies which included online materials. The material was analyzed through mixed-method, which involved description, explanation, translation, and interpretation. The result showed that the COVID-19 pandemic impacted negatively the entertainment industry, bringing to a halt the performer/audience physical participation and interaction and a lot of reduction in the socio-economic progress of entertainers and the entertainment industry depends on their audience for finance. It also opened up the need for the entertainment industry to focus more on the acquisition of E-entertainment facilities to bridge the gap between the entertainers and the audiences on a larger scale to take care of pandemic incidents like COVID-19.
\end{abstract}

Keywords: Entertainment, Music, Lockdown, Covid-19, Pandemic, Fans, Artistes

\section{Introduction}

Covid-19 has been described as an infectious disease that causes respiratory infections and it originated in Hunan seafood market at Wuhan China (Obi-Ani, Anikwenze and Isiani,2020:2). The first case was recorded on November 17, 2019(Aguisi et al,2020:1). The symptoms of Covid-19 range from fever, cough, respiratory system, and shortness of breath and breathing difficulties (Ohia, Bakarey and Ahmad, 2020:279). The first index announced case of Covid-19 in Nigeria was on 27 February 2020. That was the case of an Italian visitor who got it and spread to a Nigerian whose case was confirmed on march 92020 thus becoming the first recorded cases in Sub Saharan Africa (Amoo et al 2020: 2). For a period of one month between February 27 to March 27 2020, reported cases of Covid-19 was mainly from returned travelers (Amzat,2020:2).

(c) AesthetixMS 2021. This Open Access article is published under a Creative Commons Attribution Non-Commercial 4.0 International License (http://creativecommons.org/licenses/by-nc/4.o/), which permits non-commercial re-use, distribution, and reproduction in any medium, provided the original work is properly cited. For citation use the DOI. For commercial re-use, please contact editor@rupkatha.com. 
The virus regrettably has no cure for now. While the ongoing clinical trials of the vaccine for COvid-19 was ongoing, Russia through its ambassador to Nigeria Alexey Shebarshin made available, sample of Russian COVID-19 vaccine to the Federal Ministry of Health in Nigeria which was at a time being tried by other countries of the world such as the United Arab Emirates (UAE), Saudi Arabia, Mexico and several others (Ezeh, 2020:29). While countries of the world were recreating new medical breakthroughs on COVID-19, Nigeria was expecting and relying on innovations being created by the West. Even herbal cure from African countries like Madagascar was politicized by the National Institute of Pharmaceutical Research and Development (NIPRD) who alleged that it could only reduce cough associated with COVID-19 and not a corrective medicine (Taiwo-Obalonye, 2020:8). Yet Madagascar has no recorded death from COVID-19 pandemic. The global suspicion that Coronavirus was Chinese biological weapon was nothing frightening to the Nigerian government as they hurriedly invited 15 Chinese medical experts to assist her fight COVID-19 in Nigeria which was out rightly rejected by the masses. Following this development, the Nigerian Health Minister Dr.Osigie Ehanire diplomatically maintained that China Civil Engineering Construction Corporation (CCECC) invited them to Nigeria (Emorinken, 2020:8).

The outbreak of COVID-19 pandemic is yet another wake up call for scientific breakthrough. Within a short time-frame, manufacturing of Personal Protection Equipment (PPE) and other medical facilities was beginning to be produced locally due to shortage of medical equipments coming from abroad as a result of COVID-19 pandemic and the increase demand of medical equipments. It should be recalled that following the outcome of the Nigerian Civil War between 1967 to 1970 , there was huge success recorded in the scientific breakthrough recorded in the defunct Biafra as necessity became the mother of invention. Under heavy threats of war, aero planes were maintained, oil was refined, and there was local manufacturing of bombs known as Ogbunigwe and other war implements in the midst of difficulties and scarcities.

The first recorded case of COVID-19 announced on 27 February 2020 in Nigeria came out with its own challenges. Specifically, the COVID-19 outbreak was a challenge to Nigeria's creative ingenuity. Obinna (2020:17) recorded that there was a sharp increase in the cost of hospital equipments. According to him,

Cost is one of the impacts of COVID-19 on health services. Prices of most of the consumables used in hospitals have skyrocketed. For example, the infrared thermometer sold for $\mathrm{N}_{5}$,ooo was sold for $\mathrm{N}_{75}$, ooo between March and April. And of course, other medical equipments and Personal Protective Equipment (PPE) such as hand gloves and hand sanitizers.

At the Federal Polytechnic Nakede in Owerri there was the invention of manual and automated hand washing sanitizer machines to combat COVID-19(Njoku, 2020:3). Also, at the Federal Polytechnic Oko in Anambra State, there was the construction of automated solar power anti COVID-19 machines produced by engineers from the institution. It was designed in a way that once the water and sanitizers dispensers are filled over 1,ooo persons could use it (Okopoly Unveils Automated,2020:14-15). In the acute shortage of ventilators and other medical equipments, the Federal government was seeking solutions to the problem of the health sector through local manufacturing. The federal government indicated interests of investing to boost the manufacturing sector to the tune of $\mathrm{N}_{5} \mathrm{Oo}$ billion but as usual it will likely end on the pages of the newspapers. The implication here is that the COVID-19 outbreak was a major challenge not only to the innovative spirits of the people but the creative minds in the entertainment industry we have set to examine. 
As of 16th of September 2020, 126 new confirmed cases and 3 Covid-19 related deaths have been recorded in Nigeria, with a total of 56,604 confirmed cases, 47,872 discharged and 1091 deaths recorded in 36 states of the federation (COVID-19 NIGERIA, 2020: https://covid19.ncdc.gov.ng/). The table below captures the COVID-19 index in Nigeria as recorded by the Federal government-owned Nigerian Centre for Disease Control (NCDC). The emphasis of this paper, however, is not on the demographic analysis of the Covid-19 pandemic or the history of its outbreak. This is because existing scholarship has handled the aforementioned themes (Aguisi et al, 2020). The focal point of the analysis is on how the pandemic has affected the entertainment industry in Nigeria.

\begin{tabular}{|c|c|c|c|c|}
\hline States Affected & $\begin{array}{l}\text { No. of Cases (Lab } \\
\text { Confirmed) }\end{array}$ & $\begin{array}{l}\text { No. of Cases (on } \\
\text { admission) }\end{array}$ & No. Discharged & $\begin{array}{l}\text { No. of } \\
\text { Deaths }\end{array}$ \\
\hline Lagos & 18,723 & 3,273 & 15,245 & 205 \\
\hline FCT & 5,488 & 522 & 4,892 & 74 \\
\hline Oyo & 3,223 & 1,082 & 2,102 & 39 \\
\hline Plateau & 3,158 & 969 & 2,158 & 31 \\
\hline Edo & 2,610 & 78 & 2,427 & 105 \\
\hline Kaduna & 2,305 & 90 & 2,182 & 33 \\
\hline Rivers & 2,208 & 29 & 2,120 & 59 \\
\hline Delta & 1,793 & 106 & 1,638 & 49 \\
\hline Ogun & 1,755 & 22 & 1,705 & 28 \\
\hline Kano & 1,733 & 26 & 1,653 & 54 \\
\hline Ondo & 1,590 & 65 & 1,490 & 35 \\
\hline Enugu & 1,232 & 123 & 1,088 & 21 \\
\hline Ebonyi & 1,034 & 7 & 997 & 30 \\
\hline Kwara & 1,004 & 77 & 902 & 25 \\
\hline Katsina & 844 & 363 & 457 & 24 \\
\hline Abia & 835 & 35 & 792 & 8 \\
\hline Osun & 805 & 17 & 771 & 17 \\
\hline Gombe & 779 & 75 & 679 & 25 \\
\hline Borno & 741 & 2 & 703 & 36 \\
\hline Bauchi & 681 & 11 & 656 & 14 \\
\hline Imo & 551 & 323 & 216 & 12 \\
\hline Benue & 467 & 57 & 401 & 9 \\
\hline Nasarawa & 447 & 137 & 298 & 12 \\
\hline Bayelsa & 393 & 2 & 370 & 21 \\
\hline Jigawa & 322 & 3 & 308 & 11 \\
\hline Ekiti & 305 & 33 & 267 & 5 \\
\hline Akwa Ibom & 286 & 27 & 251 & 8 \\
\hline Niger & 244 & 16 & 216 & 12 \\
\hline Anambra & 232 & 29 & 184 & 19 \\
\hline Adamawa & 230 & 19 & 196 & 15 \\
\hline Sokoto & 159 & o & 142 & 17 \\
\hline Taraba & 95 & 16 & 73 & 6 \\
\hline Kebbi & 93 & 1 & 84 & 8 \\
\hline Cross River & 83 & o & 74 & 9 \\
\hline Zamfara & 78 & $\mathrm{o}$ & 73 & 5 \\
\hline Yobe & 73 & 6 & 59 & 8 \\
\hline Kogi & 5 & o & 3 & 2 \\
\hline
\end{tabular}

Source: Confirmed Cases by State, https://covid19.ncdc.gov.ng/ accessed 17 September 2020 
The deadly Coronavirus, also known as COVID-19, had an impact on the entertainment industries in Nigeria. The music performing industries were the worst hit of the lockdown. The usual method of entertainment in Nigeria had always been an outdoor method. This implies that people need to move out to dance halls, clubs or event places in order to get entertained. Following the lockdown of markets, schools, clubs, offices, parks, churches, mosques and other public places in order to checkmate the community spread of the virus. An editorial of reputable journal reveals that a good proportion of the entertainment industry depends on audiences and experiences that involve physical proximity which involves entertainers such as actors, musicians and dancers except for material artists and fashion designers (Editorial, 2020:93). There was a major setback on the entertainment industry in Nigeria because part of the measures put in place to checkmate the spread of the deadly virus by the Nigerian government was to legislate against open get-together (Hassan,2020:32)

The entertainment industry is not always considered when measuring the national economy in Nigeria. This is because the emphasis has always been on oil and gas, manufacturing, telecommunications and agriculture. The Nollywood for example is reputed to be the secondlargest film industry in the world in terms of the number of films produced annually. This is because an average of fifty films is produced weekly across the country enjoying the services of approximately 100 persons per project which include actors, directors, producers, sound engineers, costume engineers, line producers, welfare coordinators, editors, continuity supervisors and this amount to about 5,000 jobs lost every week and since the lockdown began an average of 40,000 jobs as of May 2020 was lost (COVID-19:250 Jobs at Stake, 2020:21).

Justifying the losses encountered in the entertainment industries, the News Agency of Nigeria reported that the cinema in Nigeria earned over N3billion in the first half of 2019 and over N1.2 billion in July while the Cinema Exhibitors Association of Nigeria recorded that in 2019 Nigeria spent almost $\mathrm{N}_{7}$ billion to view films in the cinemas across Nigeria but the outbreak of Covid-19 has brought uncertainty in the industry, such that no one can predict what the outcome will be in terms of income generation (Aguda, 2020:10). With the outbreak of the Covid-19 pandemic, the Cinema Exhibitors Association of Nigeria (CEAN) in connection with Film and Motion Distributors Association of Nigeria (FDAN) began strategizing on how to manage social distancing in Cinema by sending out messages to their members on social media platforms. The initial plan to remain in business was to reduce the capacity of the hall to only 50 percent in order to allow space seating, allow only customers with face mask, and check the temperature of people coming into the hall, as well as print online tickets. These measures were put in place anticipating partial lockdown but this did not materialize as the lockdown was extended severally by Federal government on the instruction of NCDC (Covid-19:250 Jobs at Stake,2020:21). Thus, the projected arrangement could not sail through because of the government insistence on continued lockdown in order to checkmate the community spread of the Covid-19 pandemic.

By July 2020, the Cinema in Nigeria was still at lockdown. This had serious economic implications for those practitioners in the entertainment industries. As a result, the Nigerian Cinema Exhibitors Association of Nigeria (CEAN) sent a Save-Our Soul appeal to Nigeria's President Muhammadu Buhari for the reopening of the theatrical sector of the economy alleging that their association had lost over 50 million USD (about 22.5 billion) and more than 5,0oo jobs since the lockdown was imposed by the Nigerian government. In addition, they re-affirmed that annual revenue of N20o billion was being realized in Nigeria by making films (Cinema Films Operators Cry to Buhari,2020:3) 
The negative effect of the Covid-19 led the Director General National Council of Arts and Culture Otunba Olusegun Runsewe to admit that people in the entertainment sector was the worst hit by the socio-economic implications of the lockdown since practitioners in the industry are very close to the people (Anokwuru,2020:43). The Nigerian musicians had their own fair share of the lockdown effect. Top Nigerian artistes like 2 Face Idibia, Davido, Asa and Sinach had their tours in Cameroon, North America and London postponed and already sold tickets cancelled and money realized, credited back to the owners. There were several cancellations of big shows, many music albums that were supposed to be released were placed on hold and many of the singles which were supposed to have been released were held back (Nigeria: Coronavirus Compels,2020). The lockdown was a period of uncertainty as the artistes were also looking at the general mood of the people that were seeking of pleasure with the fear that accompanied the Covid-19 pandemic.

\section{E-Entertainment During the Lockdown}

The beginning of the Coronavirus pandemic lockdown also brought so many positive innovations. The private sector and the government resumed meetings via Skype, Webiner and Zoom to communicate and deliberate on issues. The Nigerian artistes were left with the option of using YouTube, Twitter, Facebook, Telegram and Instagram to do their shows. Many Nigerian artistes like Seyi Shay, Reekado Banks, Timi Dakolo, Semi, Falz, Burna Boy, Flavour, Phyno and others explored the option of YouTube Live shows and streaming to remain in business. There was feedback from fans that used Mark Zuckerberg's Facebook to make requests from entertainers on what kind of performance and songs they wanted and as well expressed their feelings of the performances (Olalekan, 2020.)

Creative minds are always coming up with new strategies in every circumstance. Covid-19 pandemic provided new opportunities for creativity. Nigerian artistes like the Hip-pop awardwinning artiste, Tu Face Idibia, in conjunction with the International Breweries PLC, makers of the Trophy Extra Stout, had an E-concert. The idea was to bring fun and hope to thousands of people in the comfort of their homes was the first of its kind (Tuface Dazzles Fans,2020:22). In a related development, another group of artistes Asa and Davido organized a show through music steaming platform Udu X live stream on 13 April 2020 (Olalekan, 2020). There was yet another major e-concert by popular musicians Flavour and Phyno which was hosted on Instagram live sessions. It was one way of overcoming the boredom created by the Covid-19 pandemic. It was hosted every Friday nights as the Beer Parlour conversations and was anchored by WAGA-G. It began on Friday night, May 1, 2020, and was sponsored by The Life Beer brand ambassadors who used the opportunity to unveil the life beer brand campaign titled "Ndu Ka - Life is Important" Live on Instagram and other social media platforms (Kwentua,2020)

Similarly, the $7 \mathrm{UP}$ bottling company sponsored a live-streamed concert through the following DStv packages - Premium, Compact Plus, Compact, Confam and Yanga; and GOtv packages. It was called 'Turn Up Friday with Pepsi' and Doztun a great dancer was the host. The broadcast lives every Friday for three hours from 9:30 pm-12:30 am got viewer enjoying DJ Obi who kick-started the show, DJ Neptune, DJ Sose, DJ Lambo, DJ Consequence and many more. Beginning from the middle of April 2020, the show was bringing DJ music party to everyone right in their living rooms and Africa Magic through DSTV channels 153 and 154 driving fun and excitement into many Nigerian homes. The programme was also live on Amazon Prime Video, Apple, Twitch, YouTube, BBC and a number of TV networks. During the Friday programmes, fans who recorded their dance steps on Facebook, Instagram and twitter handle of the TV show were 
shown live during the programme (Onwuaso,2020). The event also played host to notable media personalities, comedians and musicians like Tiwa Salvage, Eaze, Kaffy and so many others.

Furthermore, there was Live Owambe on Am Urban and family every Saturday at $8.30 \mathrm{pm}$ through DSTV channels 153,154 and GOTV channel 2. The programme was hosted by a popular radio host and media personality Steve Onu popularly known as Yaw and was sponsored by the Indomie Noodles (Obinna, 2020). The outbreak of Covid-19 had implications for public performances and the popular Owambe parties in Yoruba land were banned (Okunbor and Ogundele, 2020:38). The viewers of DSTV Africa had a great time every Saturday enjoying the live show on television. The Owambe feeling was brought every Saturday to many homes of the viewers as a way of making them forget the challenges of the Coronavirus lockdown. The host of the show Yaw was able to attract notable Nigerian artistes who performed with live bands on television and the people made the request through various social media platforms. Notable artists that performed during the shows include Flavour, Sir Shina Peters, and major musical bands in Nigeria (Excitement as SSP, 2020:20)

At the continental level in Africa, there was a virtual live solidarity concert for Africa Union and All Africa Music Awards (AFRIMA) to commemorate 2020 Africa Day Celebration (AU, AFRIMA Fight COVID-19,2020:29). In an E-Concert hosted by the comedian, Bovi called Naira Win Verbal Concert, the fans of Davido, Tiwa Salvage, Mayokurn and others were entertained in August 2020 by the aforementioned music stars through e-concert in order to observe the Covid19 lockdown (Ihekire,2020). There was also a wonderful innovation introduced by Ice Nweke for the virtual convention for dancers. The idea was to use professional dancers like Kafayat Oluwatoyin Shafau known as Kaffy to train a generation of dancers online through creating numerous jobs and opportunities through that process (Eniola,2020:12)

In addition, there were other ways of exploring e-concerts and online platforms for advancing their creative ingenuity. The popular filmmaker Tunde Kelani during the lockdown was able to release on YouTube the adaptation of the novel published in 1952 by Amos Tutola titled the Palmwine Drunkard (Ganlu, 2020:12). At the same period the popular Nigerian musician, Davido, released on YouTube in his 2019 hit 'Blow My Mind' which was accessed by about 40 million viewership (Bada, 2020:20). The closure of the cinema halls gave an opportunity for Pay-Tv companies like DSTV to showcase interesting love programmes like Mercy and Ike of the Big Brother Naija 2019 fame which showcases on Monday and Fridays on African Magic Urban with a repeat broadcast scheduled on Mondays and Tuesdays for those who missed Sunday shows (Aguda,2020)

Sometime in July 2020, the virtual meeting of the Director National Film and Video Census Board Adebayo Thomas and his Kenyan counterpart Dr Elizabeth Mutua after their deliberations on the film industry noted some observations. The maintained that the COVID-19 has ravaged the film industry and appealed to the government to approve the reopening of cinema while they abide by the World Health Organization (WHO) protocols (Nigeria, Kenyan Film Regulation,2020:39)

\section{Stress, Support and Palliatives for the Creative Industry during the Covid-19 Pandemic}

During the lockdown, Nigerian artistes, actors and actress were stressed out and had issues with the government of the day. Nigerian artistes ordinarily are not used to caged life and as a result, contravened the social distancing law meant to checkmate the community spread of the Covid-19 
pandemic. An artist, Funke Akindele of the popular Jenifa's Diary and one of the Nigerian popular singers, Naira Marley, are reference points to this claim. Sometime in April 2020, Funke Akindele arraigned before a Lagos Magistrate Court with the husband and the charge read as follows:

That you (1) Funke Akindele(2) Abdul Rasheed Bello on the $4^{\text {th }}$ day of April 2020 at 9, Gbdamosi close, Amen Estate, Ibeju Lekki in the Lagos Magisterial District gathered at the aforementioned address with 20 persons contrary to the social distancing directive of Mr. Governor of Lagos State Infectious Disease Emergency Prevention Regulation 2020 and thereby committed an offence punishable under section 58 of Public Health Law Cap P.16 Vol.9 Laws of Lagos State 2015(Okonkwo,2020:32)

Funke and the husband pleaded guilty and were requested to engage in community service in Lagos State for two weeks. Also arrested but later released was another artiste, Naira Marley. Meanwhile, the court premises were filled with people who during the trial also negated the social distancing law while trying to implement the law. On 13 June 2020 Naira Marley flew to Abuja, with a charter flight for a concert. The event, which took place at Jabi Lake Mall led to the sealing off of the premises. Ten days after, the premises were re-opened but the artiste Naira, who pleaded guilty was arraigned on August 72020 before Abuja Mobile Court where- he pleaded guilty and paid a fine of N200,00o(Okonofua,2020)

Notwithstanding some of these face-offs between few artistes and the government, the situation created by the Covid-19 pandemic called for support from the government and concerned individuals. The Federal government on its own was able to give a lifeline to television and radio stations as a way of salvaging about $\mathrm{N}_{7.8}$ billion debt from license fees. The indebted stations were by this offer expected to pay only 60 per cent of their debt beginning from July to October 2020 (Falashade-Kayi,2020:27)

The Copyright Society of Nigeria announced its resolve to distribute N50 million to musicians in its register to curtail the effect of Covid-19(GaniuA,2020:16). In a related development, buoyant musicians also gave out palliatives to cushion the effect of Covid-19. Tuface Idibia a Nigerian musician announced No million donations to support the fight against Covid19(Ganiu B 2020:21). In addition, Mr Eazi in May 2020 announced his readiness to give meals to 10,000 residents of Lagos (Unamaka,2020:19) As part of its social corporate responsibility the Access Bank Nigeria PLC supported at the beginning of the Lockdown the Africa International Film Festival (AFRIFF). The idea was to nurture filmmakers in a pioneering new vision for the industry as well as all those in the industry's value chain. This event was accompanied by talent hunts that will drive new leaders in the industry. (Access Bank Bridges..,2020: 12)

The entertainment industry at the height of Covid-19 pandemic was able to navigate to some extent the difficulties associated with the Covid-19 pandemic. However, the poor network most times constituted a hitch in accessing live performances. The cost of data was not reduced as pleaded by the government during this period thus making life difficult for people who ordinarily are subscribing in other to get entertained. The rainy season also affected the DSTV subscribers who ordinarily will get the best service each time it rained. There were severe challenges orchestrated by the epileptic supply of electricity and even the hike in tariff and petroleum products which directly affected the entertainment industries.

\section{Sports Entertainment during COVID-19 Lockdown}


The significant impact of COVID-19 on sports development in Nigeria cannot be overemphasized. The forces of globalization have really shaped sports behavior in Nigeria as every sports lover is attached emotionally to one league, athlete, and games or engaged in bet games. The collapse of sporting events due to COVID-19 lockdown affected the grass root people to a great extent. Sports related business, television, advertising, and marketing suffered tremendously. Under this circumstance, various sports agencies felt some share of responsibility to reach out sports organizations.

A report has it that sports content such as football in Nigeria is huge. But owing to the pandemic, organizers of notable leagues across the globe got re-scheduled due to COVID-19 pandemic. The gap was however being bridged notably by the Supersport the big sports content provider in DSTV and GOTV platforms. Late in March 2020, the provider launched the Believe campaign an exciting sports show created to highlight the greatest stories in sports, relief offer football, golf, UFC the opportunity to see epic matches, documentaries and interviews from the past (Aguda,2020:10).

Even with some of the aforementioned measures put in place, food vendors, bars, restaurants and other related chains of businesses suffered. Customers could not patronize for several reasons. More directly is the fact that new matches were not being fixed and televised. The impact of this development is a hypothesis for waiting for its researchers as bet games that accompanies football events was no longer there. The direct impact of this development was the increase in criminal activities. The rise of criminal group known as "One Million Gang" created fear in Lagos that each neighborhood in the city during the COVID-19 lockdown quickly organized its own security in the absence of the willingness by the police to protect the people. (Orji,2020). Sporting events ordinarily serves as a yardstick of crime control a sort of. There was the Covid-19 protocol prohibiting gathering in public spaces and as well as constant harassment from security agents to that effect. For example, the National Human Rights Commission report to the Transparency International reveals that the police and other security agents in the first two weeks of the COVID-19 lockdown killed about 18 people. This number according to the report was more than the number of fatalities emanating from COVID-19 as of that time (Asimi, 2020).

Different measures were put in place to cushion the effect of economic harsh realities on those in sports value chain. The Handball Federation International gave the Handball Federation of Nigeria (HFN) the sum of USD 8,00o support fund. This was given as part of the measure put in place to reduce the negative impact of COVID-19 on handball family (COVID-19: HFN Confirms., 2020:30). In addition, the Nigerian Football Federation (NFF) got about \#180 million from FIFA as a financial relief for members passing through difficult financial challenges as a result of COVID19 in April 2020. (Apu,2020:28). The Sports Writers Association of Nigeria (SWAN) got its own fair share of \#11,580,000 (Eleven Million Five hundred and eight thousand) from the Nigeria Football Federation when eventually the money was distributed among members of Nigeria football family (SWAN Applauds NFF,2020:30).

Gradually, attention was diverted towards creating E-sports that will create employment for the youths and increase the nation's Gross Domestic Product (GDP) (Olopade, 2020:30). Following this path, the Ministry of Youth and Sports Development launched online webinars training initiatives and E-sports programmes to keep youth engaged during the COVID-19 lockdown (COVID-19: Sports Ministry Expands Digital,2020:30). Meanwhile, local entrepreneurs who own bet game shops suffered during this period as customers were not patronizing them with the closure of different European leagues and as a result there were no bet games. 


\section{Conclusion}

In this paper, we have been able to attempt a discourse on the impact of Covid-19 pandemic on the Nigerian sports, artistes and owners of cinema halls. The entertainment industry, as we have shown, could be a credible alternative to the diversification of the economic agenda as a lot of revenue is being generated from that sector. We have also pointed out that the industries have their own value chain that provides opportunities for survival for a lot of people. Following the outbreak of Covid-19 pandemic, the sector was badly affected since it deals with the person to person contact to operate. Following the outbreak of the Covid-19 lockdown that prohibited the movement of persons, travels and social gatherings, the practitioners in the aforementioned industries relied on E-concerts and online services to operate in what has become the new normal. Thus, even though there was no physical interactive performance between entertainers and their audience not much income generated due to the COVID-19 pandemic, inasmuch the income reduced due to several factors, the act of entertainment in Nigeria was still not totally hindered. In addition, we observed that sports as an agent of globalization was affected during the COVID-19 pandemic and thus was the various measures put in place to cushion the effect of the COVID-19 pandemic on the grass root people.

\section{References}

Access Bank Bridges Funding Gap in Creative Industry" (2020) The Nation Wednesday March 4.

Aguda,O. (2020) "How COVID-19 Has Affected the Film Industry"Sunday Sun, May 24.

Aguda $^{\text {B }}$ O. (2020) "How Covid-19 Pandemic Has Affected the Film Industry" https://businessday.ng/brands-advertising/article/how-covid-19-pandemic-has-affected-the-filmindustry/ accessed 13 June.

Agusi, E.R et al (2020) 'The Covid-19 Pandemic and Social Distancing in Nigeria: Ignorance or Defiance” Pan African Medical Journal, Vol. 35 Supp.2 https://www.panafrican-medjournal.com/content/series/35/2/52/full accessed 17 September.

Amoo, E.O. (2020) 'Nigeria and Italy Divergences in Coronavirus Experience: Impact of population Density" Hindawi The Scientific World Journal, http://doi.org/10.1155/2020/8923036

Amzat, G et al (2020) "Coronavirus Outbreak in Nigeria: Burden and Socio-Medical Response During the First 100 Days" International Journal of Infectious Diseases Vol. 98

Anokwuru, E. (2020) “COVID-19, Runsewe Urges Industry Players to be Alert' 'Daily Sun Thursday March 26.

Apu, J. (2020) “'COVID-19: NFF Gets \#180M FIFA Grant”Daily Sun, April 25

Asimi, S (2020) "In Nigeria, COVID-19 Brings Home the Need for Effective Criminal Justice Complaint Channel"https://www.transparency.org/en/blog/in-nigeria-covid-19-brings-home-the-need-foreffective-criminal-justice-complaint-channels\# accessed 20 Novmber 
AU, AFRIMA Fight Covid-19 (2020) Daily Sun Wednesday May 27.

Bada, G.(2020) ‘Davido Hit Song, 'Blow My Mind' Crosses 4o Million on You Tube” The Nation Saturday May 16.

Cinema Operators Cry to Buhari Over N22.5 Billion Losses” (2020) Daily Sun, Monday July 6.

COVID-19 NIGERIA, (2020): https://covid19.ncdc.gov.ng/ accessed 17 September.

COVID-19: HFN Confirms Receipt of USD 8,0oo Support From IHF' (2020) Daily Sun, Thursday August 13

COVID-19: Sports Ministry Expands Digital Training for Youths (2020) Sporting Sun, Friday April 24

COVID-19:250,00o Jobs at Stake in Creative Industry” (2020) Daily Sun, Friday May 22.

Editorial (2020) “Creative Industries Beyond COVID-19”Creative Industries Journal Vol.13 No.2

Emorinken, M. (2020) “Chinese Medics Not Our Guests, Says Minister” The Nation, Friday May 15

Eniola, O. (2020) ‘Ice Nweke’s DC-DE Holds Virtual Convention for Dancers” Guardian August 15.

Excitement as SSP Headlines Africa Magic Owambe Show (2020) Daily Sun, Friday July 17.

Ezeh, F. (2020) 'Russia Markets COVID-19 Vaccine in Nigeria” Daily Sun, Saturday September 5

Falasade-Kayi, A. (2020) 'Covid-19: FG Gives TV, Radio Station Lifeline on N7.8bn Debt” Daily Sun Tuesday July 7.

Ganiu', O. (2020) "MCSN Attacks COSON Over N50 Million COVID-19 Fund' The Nation, Wednesday April 15.

Ganiu', O. (2020) “2 Baba Donates No Million to Fight Coronavirus', The Nation, Friday Aprili5.

Ganlu, O. (2020) “Tunde Kelani Releases Palmwine Drunkard on Stage” The Nation, Wednesday May 6.

Hassan, H.A(2020) "Coronavirus COVID-19: Current Situation in Nigeria” Journal of Organic Chemistry Research, Vol.5(1)

Ihekire, C. (2020) 'Davido, Tiwa Savage to Headline E-Concert Today 'Saturday Guardian, August 15.

Kwentua, S. (2020) 'Flavour, Phyno excite consumers on Instagram Live with new Life Beer look'https://www.vanguardngr.com/2020/05/flavour-phyno-excite-consumers-on-instagram-live-withnew-life-beer-look/ accessed 13 August.

Nigeria, Kenyan Film Regulation Push For Cinema Re-Opening"(2020) Daily Sun Friday July 31.

Nigeria: Coronavirus Compels Nigerian Musicians to Rethink for Engagement Income Sources"(2020) http://Africa.com/stories/2020042/o021.html.

Njoku, C. (2020) "Nigerian Scientists Invent Equipment Against COVID-19" The Nation, Wednesday, May 6

Obi-Ani, N., Anikwenze, C., and Isiani, M.C., (2020) "Social Media and the Covid-19 Pandemic: observations From Nigeria" Cogent Arts and Humanities Vol.7, https://doi.org/10.1080/23311983.2020.1799483

Obinna, D. (2020) "COVID-19: Fresh Challenges Facing Mothers and Children in Nigeria" Daily Sun, Thursday, July 2

Obinna, E. (2020) “Africa Magic launches Indomie Owambe Saturday” https://businessday.ng/arts-andlife/article/africa-magic-launches-indomie-owambe-saturday/) Accessed 12 September.

Ohia, C., Bakarey, A.S., and Ahmad, T. (2020) "COVID-19 and Nigeria: Putting the Realities in Context" International Journal of Infectious Diseases, Vol.95

Okonkwo, K (2020) “Celebrity and the Law” Sunday Sun June 26. 
Okonofua, O. (2020) 'Naira Marley Fined N200,ooo by Abuja Court for Disregarding COVID-19 Protocols" https://www.pulse.ng/entertainment/celebrities/naira-marley-fined-n20oooo-by-abuja-court-fordisregarding-covid-19-protocols/bol140q accessed 14 September.

Okopoly Unveils Automated Solar-Powered Anti- COVID-19 Machine” (2020) Daily Sun, Friday, May 22

Okunbor, K.O and Ogundele, B (2020) As COVID-19 Ravages, the Word-Lagos, Ekiti Ban Owambe, The Nation Saturday March 21.

Olalekan, F. (2020) 'Nigerian artistes now surviving on digital shows after losing gig money to Coronavirus" https://nairametrics.com/2020/04/14/nigerian-artistes-now-surviving-on-digital-shows-after-losinggig-money-to-coronavirus/ accessed 14 September.

Olopade Reveals E-Sports Opportunities, (2020) Daily Sun, Tuesday, August 18

Onwuaso, U. (2020) 'Watch Your Favourite DJ Music and Dance Party Premieres on Africa Magic Channels' https://www.nigeriacommunicationsweek.com.ng/watch-your-favourite-dj-music-and-dance-partypremieres-on-africa-magic-channels/.

Orji, S (2020) 'Gangs Terrorised Africa's largest city in Coronavirus lockdown, Vigilantes Responded” https://www.scmp.com/news/world/africa/article/3084816/gangs-terrorised-africas-largest-citycoronavirus-lockdown accessed November 19

SWAN Applauds NFF on COVID-19 Pallatives (2020) Daily Sun, Wednesday August 12

Taiwo-Obalonye, J, Itua, F and Ezeh, F “Madagascar Herbal Remedy Can't Cure COVID-19-FG” Daily Sun, Friday July

Tuface Dazzles Fans at Trophy Endorsed E-Concert (2020) Daily Sun Friday April 24.

Unamka, S, (2020) "Mr. Eazi Gives 10,00o Lockdown Meals" The Nation Friday May 1. 